Agnieszka Franczyk-Cegła

Wrocław

\title{
Pinocciana w zbiorach Działu Starych Druków Zakładu Narodowego im. Ossolińskich
}

Hieronim Pinocci (1612-1676), włoski kupiec, rajca krakowski, sekretarz królewski, dyplomata i pisarz, który obracał się w środowisku dworskim Wazów, był wielkim miłośnikiem wiedzy ${ }^{1}$. Jego aktywność i zainteresowania naukowo-literackie przejawiały się na wielu polach - był autorem pism historyczno-politycznych, monetarnych i ekonomicznych, wydawcą „Merkuriusza Polskiego", astronomem, fizykiem i alchemikiem-amatorem, przyjacielem najwybitniejszych uczonych tamtejszych czasów. Był także bibliofilem, właścicielem imponującego księgozbioru, który gromadził od wczesnych lat młodości.

W najpełniej zachowanym inwentarzu, sporządzonym w 1704 r., już po śmierci Pinocciego, odnotowano, że jego biblioteka liczyła 1874 pozycje książkowe i rękopiśmienne ${ }^{2}$. Na księgozbiór składały się dzieła wydane w języku łacińskim, włoskim, francuskim, niemieckim, polskim, hiszpańskim, angielskim i holenderskim. Dominował język łaciński i włoski; piśmiennictwo polskie, które obejmowało w większości druki ulotne okolicznościowe, stanowiło niewielką część biblioteki (niecałe 5\%). Wśród druków znajdowały się m.in. książki o tematyce historycznej (284 pozycji), religijnej (197 pozycji), politycznej (129 pozycji), prawniczej (100 pozycji), moralnej (97 pozycji) i filozoficznej (89 pozycji), poezje (129 pozycji), dzieła z zakresu chemii (71 pozycji), retoryki (67 pozycji), astronomii (65 pozycji), medycyny (60 pozycji), matematyki i geometrii (58 pozycji) ${ }^{3}$.

\footnotetext{
1 Sylwetkę Pinocciego (w tym jego działalność bibliofilską) w wyczerpujący sposób przedstawiła Karolina Targosz: Hieronim Pinocci. Studium z dziejów kultury naukowej w Polsce XVII w., Wrocław 1967. Zob. także K. Targosz, Pinocci Hieronim, [w:] PSB, t. 26, Wrocław 1981, s. 341-343.

2 Archiwum Narodowe w Krakowie (dalej: ANK), Archiwum rodziny Pinoccich, rps 404. Odpis [w:] K. Targosz, Hieronim Pinocci..., s. 121-222. W ANK (rps 405) zachowało się kilka wcześniejszych, dużo krótszych, spisów książek sporządzonych przez samego Pinocciego lub przez nieznaną osobę.

3 Zob. M. Brahmer, O bibliotece Pinoccich, [w:] Studia nad ksiązka poświęcone pamięci Kazimierza Piekarskiego, Wrocław 1951, s. 253, przyp. 2. Na temat struktury biblioteki Pinocciego zob. tamże, s. 254-263; K. Targosz, Hieronim Pinocci..., s. 86-101.
} 
Po śmierci H. Pinocciego księgozbiór wraz z archiwum rodzinnym przeszły pod zarząd syna, ks. Rafała Pinocciego, po śmierci którego (1686 r.) pieczę nad biblioteką przejął jego młodszy brat Mikołaj. W 1704 r. kazał on sporządzić wspomniany inwentarz. Część kolekcji odnalazła się w $1817 \mathrm{r}$. wraz z księgozbiorem Jacka Augustyna Łopackiego (1690-1761)4, lekarza i archiprezbitera kościoła Mariackiego, w piwnicach krakowskiego archiwum miejskiego. W tym roku miasto Kraków przekazało zbiory J.A. Łopackiego wraz z Pinoccianą Uniwersytetowi Jagiellońskiemu. Znajduje się tam dziś ok. 360 starodruków zidentyfikowanych jako należące niegdyś do Pinocciego dzięki charakterystycznemu numerowi bibliotecznemu oraz dzięki dewizom wpisanym ręką właściciela na verso lub recto karty tytułowej: „Sustine et abstine”, „In hora perimus”, „Forti fiducia” i „Immobili fide”. Także Archiwum Narodowe w Krakowie posiada co najmniej 59 jego książek ${ }^{6}$. Poza tym sygnalizowano istnienie jeszcze tylko jednego druku z Pinocciany przechowywanego w zbiorach Zakładu Narodowego im. Ossolińskich ${ }^{7}$. Szczegółowa analiza sporządzonego w 1704 r. inwentarza oraz porównanie ok. 2000 zapisanych tamże książek z ossolińskimi zbiorami Działu Starych Druków ujawniły, że w bibliotece znajduje się więcej, dotychczas nierozpoznanych, egzemplarzy z zapiskami charakterystycznymi dla Pinocciego.

Fragment Pinocciany w księgozbiorze Ossolineum jest wyjątkowo cenny, choć niewielki objętościowo. Obejmuje on łącznie 20 tytułów w 19 woluminach, na które składa się osiem dzieł z XVI wieku oraz 12 dzieł z XVII w. ${ }^{8}$ Jest wśród nich dziewięć poloników, w tym jeden z XVI wieku: rzadki druk o tematyce gramatycznej Syntaxis autorstwa Jana Cervusa ${ }^{9}$, wydany w Krakowie w 1533 r. przez Floriana Unglera. Nieznany jest jego nakład, ale wiadomo, że po śmierci Heleny Unglerowej w 1551 r. zostało na składzie 20 egzemplarzy. Obecnie w bibliotekach polskich przechowywane są cztery jego egzemplarze: po jednym w Ossolineum i Bibliotece Raczyńskich ${ }^{10}$, dwa - w Bibliotece Narodowej ${ }^{11}$.

Łopacki nie złożył autografu na żadnym egzemplarzu pinoccianów, lecz krakowski lekarz w ogóle rzadko podpisywał swoje książki. Zob. Z. Gajda, Jacek Augustyn Łopacki. Studium z dziejów kultury medycznej w Krakowie w XVIII w., Wrocław 1969, s. 152-154. W zbiorach Ossolineum zidentyfikowano dotychczas jedną pozycję z biblioteki J.A. Łopackiego: druk Contra poetas Baptisty Mantuana (Kraków 1504), na którym właściciel podpisał się monogramem H. Ł. C. A. C [tj. Hyacinthus Łopacki Canonicus Archipresbyter Cracoviensis]. Druk ten nie należał do Pinocciany.

5 Zob. K. Targosz, Hieronim Pinocci..., s. 85.

6 Informacja Pani Bożeny Lesiak-Przybył z ANK, za którą Autorka artykułu pragnie wyrazić serdeczne podziękowanie.

7 Zob. tamże, s. 83-84; M. Brahmer, O bibliotece Pinoccich..., s. 265, przyp. 1.

Zob. załączony Spis ossolińskich druków z biblioteki Hieronima Pinocciego.

9 Sygn. BOssol. XVI.O. 532.

10 Sygn. BRacz IV.U.o.7/1.

11 Z dawnej Biblioteki Ordynacji Zamojskich pod sygn. XVI.O.226 oraz z dawnej biblioteki Tarnowskich w Dzikowie pod sygn. XVI.O.377. 
Wśród siedemnastowiecznych poloników znajdują się cztery wyjątkowo rzadkie wydawnictwa ulotne autorstwa samego H. Pinocciego: Memoriale et articuli transactionis ratione deditionis civitatis Thorunensis, celsis \& praepotentibus dominis D.D. ordinibus generalibus foederati Belgii ${ }^{12}$ i jego holenderskie thumaczenie Memoriael Ende Articulen Van het overgheven van der Stadt Thorn Soo die aende Heeren Staten Generael van de Verernighde Nederlanden.${ }^{13}$ oraz Propositio Nomine Sacrae Regiae Majestatis Poloniae \& Sveciae Celsis Et Praepotentibus Dominis DD. Ordinibvs Generalibvs Foederati Belgii Facta ${ }^{14}$, także wraz z holenderskim thumaczeniem Propositie weghen den Koningh Van Polen Ende Sveden Gedaen den 21. Augusti aen de Heeren Staten Generael Der Vereenighde Provintien ${ }^{15}$. Pierwszy druk jest opisem odzyskania Torunia przez wojska Rzeczypospolitej i Cesarstwa Niemieckiego z rąk Szwedów w grudniu 1658 r. po sześciomiesięcznym oblężeniu. Drugie dziełko jest mową wygłoszoną przez H. Pinocciego w 1658 r. w Hadze podczas misji dyplomatycznej, na którą został wysłany przez Jana Kazimierza w celu pozyskania Holendrów do ligi antyszwedzkiej. Wszystkie egzemplarze należały do księgozbioru Pinocciego.

Unikatem jest wydany w 1644 r. skierowany do studentów matematyki poradnik, jak skonstruować kostki Napiera - urządzenie wspomagające liczenie, wymyślone i opisane w 1617 r. przez Johna Napiera. Niewielkiej objętości dzieło pt. Virgulae numeratrices Naperianae, autorstwa bakałarza sztuk i filozofii Maksymiliana Czarnieckiego, wyszło spod pras Stanisława Bertutowica. Drukarz ten utrzymywał kontakty z H. Pinoccim - w 1644 r. w oficynie Bertutowica wydrukowano Epitalamium... Benjamina Krausego na ślub Pinocciego z Magdaleną Szoberówną, a w 1661 r. pierwsze dwadzieścia numerów „Merkuriusza Polskiego" pod redakcją Pinocciego sprzedawano „w Krakowie, w kamienicy Szoberowskiej na Wendecie", czyli w kamienicy Hieronima Szobera, teścia Pinocciego, której połowa należała do Włocha jako część posagu ${ }^{16}$. W inwentarzu z 1704 r. zanotowano dwie pozycje z drukarni Bertutowica - Virgulae numeratrices Czarnieckiego oraz Divi Thomae de Villa Nova vita sanctissima... Sta-

12 Sygn. BOssol. XVII-4764. Drugi odnotowany egzemplarz na świecie przechowuje kopenhaska Biblioteka Królewska.

13 Sygn. BOssol. XVII-4765. W katalogach bibliotecznych dostępnych on-line odnotowano dotychczas pięć egzemplarzy tego druku: w bibliotekach uniwersyteckich w Gent, Groningen, Lejdzie, Rotterdamie oraz w Koninklijke Bibliotheek w Hadze.

14 Sygn. BOssol. XVII-4776. Drugi odnotowany egzemplarz na świecie przechowuje kopenhaska Biblioteka Królewska, trzeci - Internationaal Instituut voor Sociale Geschiedenis w Amsterdamie.

15 Sygn. BOssol. XVII-6103. Drugi odnotowany egzemplarz na świecie przechowuje biblioteka Królewskiej Holenderskiej Akademii Nauk i Sztuk w Amsterdamie, trzeci - British Library.

16 J. Szczepaniec, Udziat drukarni Bertutowiców w akcji wydawniczej Merkuriusza Polskiego z 1661 r., „Rocznik Zakładu Narodowego im. Ossolińskich” 1974, R. 9, s. 102. 
nisława Józefa Bieżanowskiego z 1663 r. Oba egzemplarze znajdują się obecnie w bibliotece Ossolineum; pochodzą z księgozbioru wiedeńskiego Józefa Maksymiliana Ossolińskiego ${ }^{17}$.

Rzadkością bibliograficzną jest także wydany w Jełgawie (do 1918 r. Mitawa) w 1670 r. zbiór Svmmaria. Deductio Juris Illustrissimis Ducibus Curlandiae In Districtum Piltensem Competentis ${ }^{18}$. Na dokumenty, dotyczące oddania w zastaw powiatu piltyńskiego książętom Kurlandii z rodu Kettlerów podczas potopu szwedzkiego w 1656 r., składają się (oprócz historii powiatu piltyńskiego na pierwszych czterech $\operatorname{kartach}^{19}$ ):

1. Consensus Regius Illustrissimo Curlandiae Duci datus dat. 12 VI 1656 [dekret zezwalający Jakubowi Kettlerowi, księciu kurlandzkiemu, na przejęcie praw do ziem piltyńskich za zgodą dotychczasowego właściciela i starosty Ottona von Maydella];

2. Consensus Regius Domino Maidelio datus dat. 12 VI 1656 [dekret zezwalający Ottonowi von Maydellowi na scedowanie oraz sprzedaż Jakubowi praw do starostwa piltyńskiego za 30000 talarów);

3. Der Piltnischen Vollmacht = Piltensium Plenipotentia; [Inc.:] Anno 1656. Die 9. Junij post factam publicationem Ordo Equestris hic in magna frequentia comparuit; [Expl.:] Actum Hasenpothi ut supra [po czym następuje spis landratów; w części pierwszej dokumentu kolegium landratów wybiera Salomona Sackena i Emmericha von Mirbach na swoich przedstawicieli w kwestii połączenia ziem piltyńskich z Kurlandią podczas kolejnych sejmików];

4. Die letze Transaction zwischen Ihrer Fürstl. Durchl. Zu Churland und der Piltenschen Landtschafft = Ultimaria Transactio Grobini, inter Illustr[issim]um Curlandiae Ducem \& Nobilitatem Piltensem celebrata dat. 25 II 1661 [tzw. transakcja grobińska];

5. Rescriptum Regium Contra Petitores Juris Illustrissimi Curlandiae Ducis ad Districtum Piltensem dat. 30 IV 1660 [potwierdzenie praw księcia Kurlandii do ziem piltyńskich]; zaw. także:

a) [Inc.:] Serenissimi ac Potentissimi Dni Joannis Casimiri ... Plenipotentiarius. Notum testatumqu[ue] facio ... [sygn.] Casimirus Ludovicus Jewłasiewski dat. 2 IX 1660 [Kazimierz Ludwik Jewłaszewski, występujący jako wysłannik króla, wprowadza księcia Jakuba w posiadanie ziem piltyńskich w nagrodę za zasługi tegoż m.in. przy pertraktacjach pokoju w Oliwie];

17 Sygn. BOssol. odpowiednio XVII-3391 i XVII-16223.

18 Sygn. BOssol. XVII-16343.

19 Tekst streszczenia sprawy kurlandzkiej przedrukowano w: Ch. von Nettelbladt, Anecdota Curlandiae praecipue territorii et episcopatus Piltensis oder Sammlung verschiedener ... Nachrichten und Urkunden von dem Territorio und Bischoffthum Pilten ..., Greypswald-Leipzig 1736, s. 69-77. 
b) Joannes Casimirus, Dei Gratia, Rex Polonus...; [Inc.:] Vniversis \& singulis quorum interest ... significamus delatum esse ad Nos ... Ulricum a Sacken obtinuisse Rescriptum ... continens ... mandata quaedam jurisdictionem \& possessionem ... Curlandiae ... Ducis de jure Competentem convellentia dat. 25 VI 1661 [reskrypt odwołujący wcześniejszy reskrypt ze stycznia 1661 r., podważający przez króla jurysdykcję Jakuba nad Piltyniem na rzecz Ulricha von Sackena] ${ }^{20}$;

6. Michael Dei Gratia Rex Polonia... [Inc.:] Significamus praesentibus literis Nostris ... Intercessisse in Judicijs Relationum nostrarum propriarum Anno praesenti ... inter aliquot nobiles Piltenses \& ... Principem ... Jacobum ... dat. 3 VIII 1671 [potwierdzenie praw księcia Kurlandii do ziem piltyńskich];

7. Extractum ex Responsio a Serenissima Republica Poloniae \& Magni Ducat. Lithvaniae in praeterito Electionis actu ... Christophoro Heinrico a Putkamer ... \& Adamo Schubert ... die 6. Julij Anno 1669. Dato [odpowiedź króla na sejmie koronacyjnym 1669 r. dana wysłannikom księcia Jakuba Krzysztofowi Henrykowi Puttkamerowi i Adamowi Szubertowi w sprawie komisji królewskiej ustanowionej po skargach szlachty piltyńskiej w 1667 r. do rozpatrzenia kwestii przejęcia przez księcia Jakuba praw do ziemi piltyńskiej: na przyszłym sejmie sprawę wyjaśnią komisarze z obu stron sporu powołani przez króla];

8. Joannes Casimirus... [Inc.:] Universis \& singulis ... significamus ... quemadmodum Nos ad requisitionem \& instantiam Illustrissimi in Livonia Curlandiae \& Semigalliae Ducis, nonnullos Nobiles \& Incolas Districtus Piltensis... dat. 11 III 1668 [potwierdzenie praw księcia Kurlandii do ziem piltyńskich].

Wśród ossolińskich druków obcych z biblioteki H. Pinocciego siedem dzieł zostało wydanych w języku łacińskim: Punica Syliusza Italika (Bazylea 1522) ${ }^{21}$, historia Germanów kronikarza Lambertusa Hersfeldensisa (Tybinga $1533)^{22}$, dzieła zebrane Francesca Petrarki (Bazylea 1554$)^{23}$, poezje Giambattisty Cinzia Giraldiego (Bazylea 1540) ${ }^{24}$, De Bosporo Thracio... Pierre'a Gille-

20 Pozycje 1-5 wychodziły najprawdopodobniej samoistnie w latach ogłaszania dokumentów zob. Estr. XV-XVIII: 15, 113 (hasło: Deductio); 14, 370-371 (hasło: Consensus), 24, 282 (hasło: Piltyń); 25, 422 (hasło: Putkamer Henryk Krzysztof); 31, 286 (hasło: Transaction); VD17 14:700497F (hasło: Piltnischen Vollmacht). W 1670 r. wydano w Jełgawie sumariusz opisywanej sprawy z osobną strona tytułową, gdzie zebrano druki wymienione w poz. 1-5, a tytułem wstępu opatrzono je streszczeniem. Kolejne dokumenty w sumariuszu ossolińskim (poz. 6-8, z lat 1671, 1669, 1668) mogły zostać sztucznie dodane w XIX w., gdy tworzenie klocków tematycznych było w bibliotekach na porządku dziennym.

21 Sygn. BOssol. XVI.O.9592 adl.

22 Sygn. BOssol. XVI.O.9622.

23 Sygn. BOssol. XVI.F.13512.

24 Sygn. BOssol. XVI.O.9591. 
sa (Lyon 1562) ${ }^{25}$, Satyricon Petroniusza (Lejda 1604) ${ }^{26}$ oraz Annales... Franciscusa Haraeusa (Antwerpia 1623) ${ }^{27}$. Zbiór zawiera także cztery dzieła w języku francuskim: Traicté des chiffres... Blaise'a de Vigenère'a (Paryż 1587) ${ }^{28}$, La Sepmaine ou la création du monde (Genewa 1588) ${ }^{29}$, Histoire de Aurelio et Isabelle... Juana de Flores (Bruksela 1608) ${ }^{30}$ oraz rzadkość bibliograficzną - Le Mercure ou Courrier des affaires publiques (Paryż 1613) ${ }^{31}$.

Ossolińskie pinocciana są wyjątkowo interesujące i cenne również pod względem proweniencyjnym. Dwa woluminy należały niegdyś do Zygmunta II Augusta - jeden z nich zawiera Poematia G. Cinzia Giraldiego oraz Punica Syliusza Italika, drugi natomiast - Germanorum res praeclare... Lamberta z Hersfeld. Oba posiadają oprawę typową dla tomów z księgozbioru tego króla - superekslibris królewski tłoczony na okładzinie górnej oraz napis tłoczony na okładzinie dolnej: „SIGISMVNDI AVGVSTI REGIS POLONIAE MONVMENTVM ANNO 1559"32. Właścicielem klocka był następnie Baltazar Czudnikowski (Cudnikowski), bakałarz sztuk i filozofii (przed 1649), proboszcz w Krzczonowie (1661-1682), dziekan kolegiaty lubelskiej (1670, 1681) ${ }^{33}$. Drugi wolumin Zygmunta II Augusta nie nosi żadnych śladów proweniencyjnych sugerujących jego przynależność do jakiegokolwiek księgozbioru w okresie pomiędzy biblioteką królewską a księgozbiorem Pinocciego. Co ciekawe, charakterystyczny numerus currens zapisano jego ręką wyjątkowo na okładzinie górnej, a sam druk nie figuruje w spisie inwentarzowym z $1704 \mathrm{r}$. Podobnie jest w przypadku dzieła De Bosporo Thracio... P. Gillesa, które nie zostało odnotowane we wspomnianym inwentarzu, choć bez wątpienia należało do księgozbioru H. Pinocciego, bowiem ten na stronie tytułowej umieścił swoją dewizę „In hora perimus”, występującą także w innych posiadanych przez niego tomach. Obok niej Pinocci wpisał także dwa inne motta: „Nervus

25 Sygn. BOssol. XVI.Qu.11643.

26 Sygn. BOssol. XVII-10792.

27 Sygn. BOssol. XVII-20434.

28 Sygn. BOssol. XVI.Qu.11881.

29 Sygn. BOssol. XVI.O.8405.

30 Sygn. BOssol. XVII-10256.

31 Sygn. BOssol. XVII-10565. Odnotowany dotychczas jedynie w zbiorach Sächsische Landesbibliothek Staats- und Universitätsbibliothek w Dreźnie, Herzog August Bibliothek w Wolfenbüttel oraz Princeton University Library.

32 Więcej na temat „Monumentów” w zbiorach biblioteki Ossolineum zob. J.A. Kosiński, Monumenta Zygmunta Augusta w zbiorach Ossolineum, „Roczniki Biblioteczne” 1967, R. 9 (z. 1-2), s. 407-423.

33 S. Uruski, Rodzina. Herbarz szlachty polskiej, t. 2, Warszawa 1905, s. 335; Dzieje Uniwersytetu Jagiellońskiego $w$ latach 1364-1764: praca zbiorowa, t. 1, red. K. Lepszy, Kraków 1964, s. 341, przyp. 134; strona internetowa parafii pw. Wniebowzięcia Najświętszej Maryi Panny w Krzczonowie, Proboszczowie Parafii Krzczonów: (OdXVw.),[online], <http://www.parafiakrzczonow.eu/index. php?option $=$ com_content\&view $=$ article\&id $=98 \&$ Itemid $=92>(7.03 .2016)$. 
sapientiae non facile credere" $i$ „Gratia gratiam parit" 34 (fot. 1). Egzemplarz „Monumentów” oraz dzieło P. Gillesa musiały zatem oddzielić się od Pinocciany przed 1704 r. Być może stało się to $\mathrm{w}$ czasie, gdy kustoszem zbiorów rodzinnych był ks. R. Pinocci, który wbrew woli swojego zmarłego ojca ofiarował niektóre książki innym osobom. Wiadomo o jednym takim przypadku, gdy obdarowanym był biskup krakowski Jan Małachowski, który dostał od R. Pinocciego zbiór map i dzieła o treści geograficznej, lecz nie należy wykluczyć możliwości, że działo się tak częściej35. Właścicielami De Bosporo Thracio... przed Pinoccim byli wojewoda nowogródzki i miński Mikołaj Krzysztof Sapieha (1558-1638) oraz Szymon Okolski (1580-1653), dominikanin, teolog i historyk, autor trzytomowego herbarza Orbis Polonus (wszedł w posiadanie egzemplarza pracy P. Gillesa po $1641 \mathrm{r}^{36}$ ).

Wśród byłych właścicieli książek obcych wchodzących w skład Pinoc-

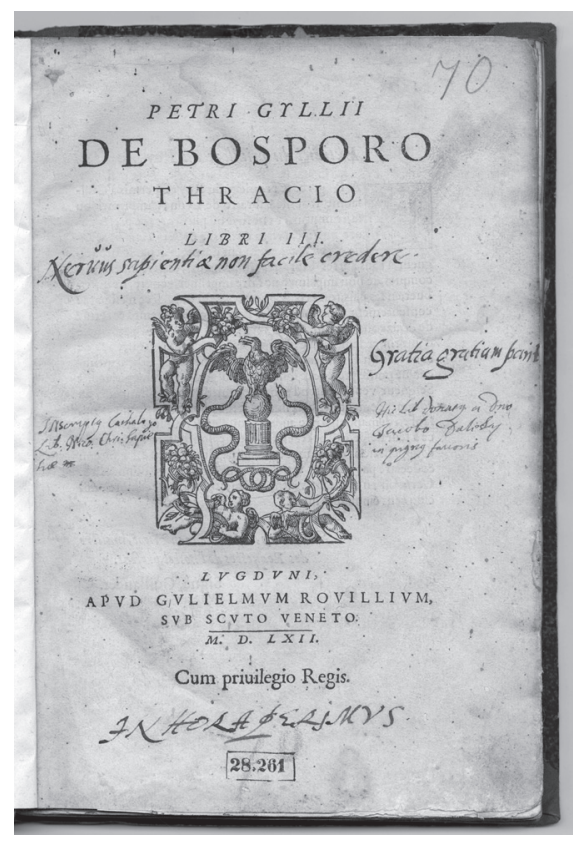

Fot. 1. Strona tytułowa dzieła De Bosporo Thracio Pierre'a Gillesa (Lyon 1562) $\mathrm{z}$ dewizami wpisanymi przez Hieronima Pinocciego: Nervus sapientiae non facile credere, Gratia gratiam parit, In hora perimus. Ze zbiorów Działu Starych

Druków Zakładu Narodowego im. Ossolińskich, sygn. XVI.Qu.11643. Zdjęcie: A. Solnica ciany był także Giovanni Michele Bruto (1517-1592), znany w Polsce jako Jan Michał Brutus, wenecki historyk i humanista. Bruto przybył do Polski w 1676 r. wraz z dworem Stefana Batorego i przebywał tu przez kolejnych dziesięć lat, zajmował się pisaniem prac historycznych. Gdy po śmierci króla przenosił się na dwór Rudolfa II, przed wyjazdem część swojego księgozbioru sprzedał ariańskiemu pisarzowi i bi-

\footnotetext{
34 Nie cytuje ich K. Targosz (zob. Hieronim Pinocci..., s. 85) przy wymienianiu dewiz wpisywanych przez Pinocciego.

35 Mikołaj, młodszy brat Rafała, był oburzony faktem rozdawania przez niego ksiąg - zob. tamże, s. 83.

36 Podpisał się na księdze jako „magister św. teologii”, który to stopień został mu przyznany w 1641 r. Zob. M. Miławicki, „Magni nominis scriptor in scribendis libris indefessus”. Życie i twórczość dominikanina Szymona Okolskiego, „Rocznik Polskiego Towarzystwa Heraldycznego” 2014, R. 13, s. 133.
} 
bliofilowi Stanisławowi Lubienieckiemu ${ }^{37}$. Nie wiadomo, co stało się z resztą biblioteki Brutusa, w skład której wchodził wolumin dzieł zebranych Petrarki wydanych w Bazylei w $1554 \mathrm{r}^{38} \mathrm{z}$ biblioteki Pinocciego. Można jedynie przypuszczać, że tom ten nie opuścił terytorium Polski, skoro znalazł się następnie w Pinoccianie; wcześniej był jeszcze w posiadaniu niezidentyfikowanego Georga Mantla. Na przełomie XVIII i XIX w. jego właścicielem był Józef Maksymilian Ossoliński ${ }^{39}$.

Dwa woluminy z ossolińskich pinoccianów były darem dla H. Pinocciego od Pierre'a des Noyers, sekretarza Marii Ludwiki Gonzagi, który - zainteresowany astronomią $\mathrm{i}$ astrologią - korespondował z najwybitniejszymi uczonymi tamtego okresu. $Z$ listów dworzanina wyłania się obraz Pinocciego jako czło-

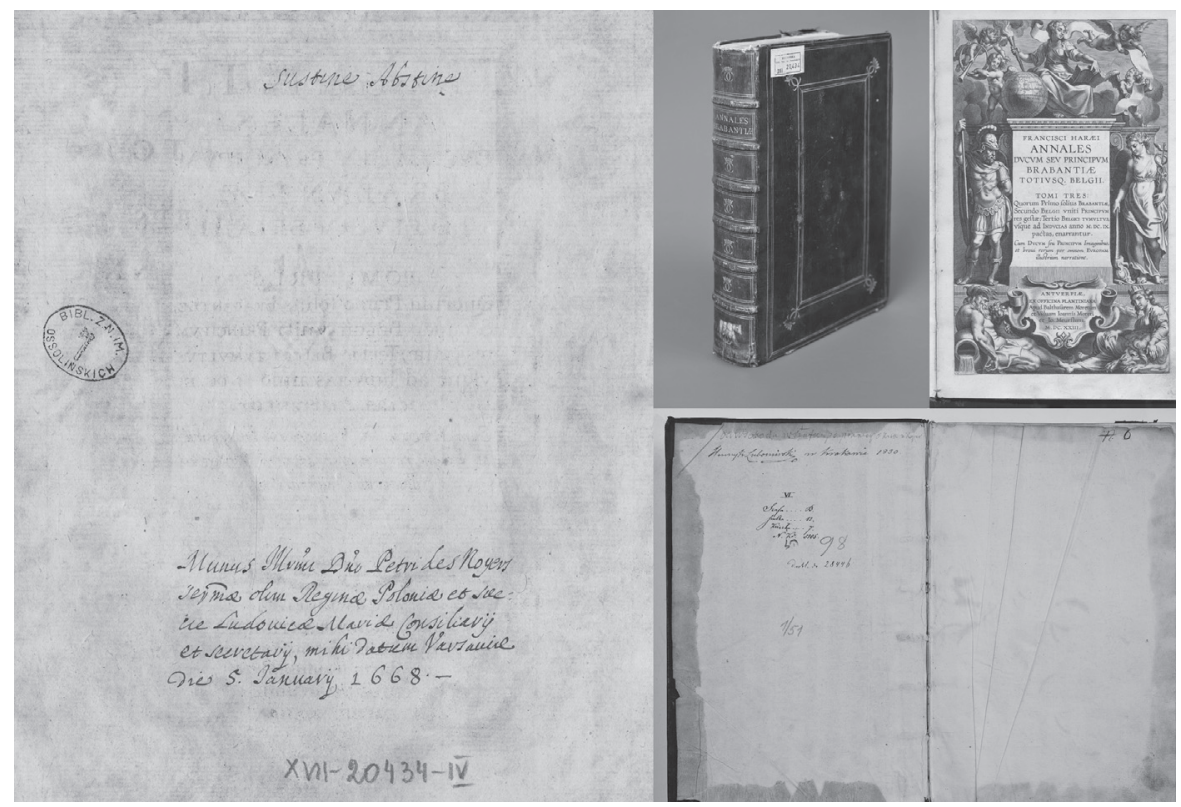

Fot. 2. Annales ducum seu principium Brabantiae totiusque Belgii

Franciszka Haraeusa (Antwerpia 1623). Od lewej : verso karty tytułowej w wpisami rękopiśmiennym Hieronima Pinocciego, oprawa, karta tytułowa, wyklejka z wpisami własnościowymi Lubomirskich i karta przedtytułowa z numerus currens Pinocciego w prawym górnym rogu.

Ze zbiorów Działu Starych Druków Zakładu Narodowego im. Ossolińskich, sygn. XVII-20434. Zdjęcie: A. Solnica

37 Zob. J. Tazbir, Księgozbiór Stanisława Lubienieckiego, „Rocznik Biblioteki Narodowej” 1968, R. 4, s. 198.

38 Jak wynika z inwentarza biblioteki St. Lubienieckiego, nie weszły one w skład jego biblioteki-zob. tamże, s. 204-217.

39 Sygn. BOssol. XVI.F.13512. 
wieka, który z zapałem gromadził książki, przesyłał publikacje drukowane w Polsce swoim przyjaciołom we Francji, rozprowadzał dzieła Jana Heweliusza na dworze polskim i w Paryżu oraz sprowadzał francuskie publikacje naukowe dla siebie i pozostałych uczonych z dworu polskiego ${ }^{40}$. W $1661 \mathrm{r}$. des Noyers podarował Pinocciemu Traicté des chiffres... Vigenère'a ${ }^{41}$, a 5 I $1668 \mathrm{r}$. w Warszawie - Annales ducum seu principium Brabantiae totiusque Belgii... Haraeusa (fot. 2). Obie książki stały się później własnością księcia Henryka Lubomirskiego, kuratora Zakładu Narodowego im. Ossolińskich.

Ossolińskie egzemplarze z księgozbioru Pinocciego trafiły do biblioteki Zakładu w XIX-XX w. z kilku różnych źródeł: jako dar fundacyjny J.M. Ossolińskiego (dziesięć dzieł), jako dar H. Lubomirskiego (pięć dzieł), jako nabytek zakupiony przez Zakład na aukcjach lwowskich w latach czterdziestych XIX w. (trzy dzieła w dwóch woluminach), jako dar Grzegorza Szymonowicza (jedno dzieło), z nieznanego źródła (jedno dzieło).

Ossoliński zdobył książki z księgozbioru Pinocciego w 1807 r., gdy Józefat Wiślicki, zarządca archiwum miejskiego w Krakowie, gdzie przechowywano część pinoccianów w zbiorze J.A. Łopackiego, pozwolił Józefowi Maksymilianowi przeglądać i wynosić zbiory archiwalne. Polski historyk, kolekcjoner i antykwariusz Ambroży Grabowski zanotował we Wspomnieniach:

za każdą wizytą przynosił stamtąd [tj. z archiwum - A.F.-C.] hrabia [Ossoliński - A.F.-C.] porządne pliki papierów, wiązane w ścierki czy serwety, które za nim tam zanosił lokaj i węzły stamtąd wynosił. [...] A były te pliki czy węzły pieczętowane; mimo to jednak raz dostrzegłem, że były w jednym węźle takim rękopisma w języku włoskim i bynajmniej nie wątpię, że to były rękopisma po Hieronimie Pinoccim ${ }^{42}$.

Wśród zabranych przez J.M. Ossolińskiego rękopisów były także przechowywane obecnie w Zakładzie książki. Kolekcjoner zdobył w ten sposób dziesięć tytułów z kolekcji Pinocciego; oprócz dwóch (egzemplarza z biblioteki Zygmunta II Augusta oraz dzieł zebranych Petrarki) są to druki niepozorne, często kilkukartkowe, niczym się niewyróżniające pod względem edytorskim lub tegumentologicznym. Nie dziwi zatem fakt, że A. Grabowski nie zwrócił na nie uwagi. Ich wartość bibliograficzna jest jednak ogromna - niektóre są unikatami lub rzadkościami na skalę światową.

H. Lubomirski podarował Zakładowi pięć dzieł, które niegdyś wchodziły w skład Pinocciany. Nie noszą one jednak żadnych znaków własnościowych

40 Zob. K. Targosz, Uczony dwór Ludwiki Marii Gonzagi (1646-1667). Z dziejów polsko-francuskich stosunków naukowych, Wrocław-Warszawa-Kraków 1975, s. 87.

${ }^{41}$ Sygn. BOssol. XVI.Qu.11881.

42 A. Grabowski, Wspomnienia, t. 2, Kraków 1909, s. 93-94. 
wskazujących, kto mógłby być ich właścicielem pomiędzy H. Pinoccim a H. Lubomirskim. Jedynie w Annales... Haraeusa znalazła się odręczna notatka Lubomirskiego o tym, że nabył ten egzemplarz w Krakowie w $1830 \mathrm{r}$. Wolumin ten, cenny także ze względu na oprawę (czerwony marokin z tłoczonym monogramem C.C. i koroną), trafił do zbiorów Ossolineum w 1949 r. po oddaniu Zakładowi biblioteki Lubomirskich z Przeworska. Pozostałe książki przekazali Ossolineum spadkobiercy Lubomirskiego w 1869 r. na mocy porozumienia z J.M. Ossolińskim z 1823 r.

W 1840 r. na lwowskiej aukcji księgozbioru po Józefie Dobku Dzierzkowskim Zakład Narodowy im. Ossolińskich nabył dzieło De Bosporo Thracio... P. Gillesa ${ }^{43}$. Dzierzkowski zmarł w 1830 r., zapisawszy Ossolineum swoje cenne zbiory, lecz testament i część cymeliów (157 druków) zaginęły ${ }^{44}$ i dopiero dziesięć lat po śmierci kolekcjonera do Zakładu trafiło kilkadziesiąt pozycji z jego księgozbioru - 27 dzieł drukowanych w 78 woluminach i 79 rękopisów jako dar spadkobierców oraz 67 druków jako nabytek aukcyjny. Drugim egzemplarzem z pinoccianów kupionym przez bibliotekę ossolińską na aukcji był jeden z „Monumentów” Zygmunta Augusta Germanorum res praeclare... Lamberta z Hersfeld. Kodeks należał do dużej i cennej kolekcji Walentego Kraińskiego, profesora lwowskiego gimnazjum. Odziedziczył ją po nim jego brat, Józef Kraiński, kanonik i proboszcz bełzki ${ }^{45}$, który zmarł w styczniu $1838 \mathrm{r}$. W inwentarzu spisanym w maju 1838 r. na polecenie urzędu komorniczego we Lwowie odnotowano 5053 poz. książkowe i 147 map (plus 13 dodatkowych tytułów spisanych osobno i oznaczonych literami A-N $)^{46}$. Na licytacji publicznej, która odbyła się na przełomie grudnia 1844 i stycznia 1845 r., Zakład Narodowy im. Ossolińskich nabył m.in. dzieło Lamberta z Hersfeld za sześć krajcarów ${ }^{47}$.

Darem przeznaczonym dla Ossolineum był natomiast wolumin Satyrico$n u$, który z rąk jezuity Adama Staudego trafił do kolegium tego zgromadzenia w Przemyślu ${ }^{48}$, a następnie do biblioteki katedry ormiańskiej we Lwowie.

\footnotetext{
43 Lwowska Narodowa Naukowa Biblioteka Ukrainy im. W. Stefanyka (dalej: BSt.) 54/IV/78, k. 2 v. nlb., poz. 42 .

${ }_{44} \mathrm{Tj}$. zostały w tajemnicy sprzedane. Podejrzanym był bratanek J.D. Dzierzkowskiego, późniejszy pisarz i publicysta Józef Dzierzkowski. Zob. K. Stefanicka, Dwóch Józefów Dzierzkowskich w historii Zakładu Narodowego im. Ossolińskich, „Ze Skarbca Kultury” 1967, t. 19 s. 62-98.

45 Zob. F. Radziszewski, Wiadomość historyczno-statystyczna o znakomitych bibliotekach $i$ archiwach publicznych i prywatnych... w Królestwie Polskiem, Galicji, W. Ks. Poznańskiem i zachodnich guberniach państwa rosyjskiego, Kraków 1875, s. 2.

46 BSt. 4/I/669.

47 BSt. 54/I/28, k. 48r., poz. 132.

48 Zob. BOssol. XVII-10792.
} 
Księgozbiór kapituły ormiańskiej w 1866 r. został przekazany Zakładowi przez ówczesnego arcybiskupa Grzegorza Szymonowicza ${ }^{49}$.

Wpisy proweniencyjne pozwalają zatem zrekonstruować fragmentarycznie historię Pinocciany po śmierci pierwszego kolekcjonera. Rozpraszany już wkrótce po śmierci H. Pinocciego, księgozbiór ten pojawił się na polskim rynku antykwarycznym (Kraków, Lwów) przed 1830 r. Czy były to woluminy przechowywane z księgozbiorem J.A. Łopackiego w krakowskim Archiwum Miejskim, które przed przekazaniem do Biblioteki Jagiellońskiej w 1817 r. zostały wyniesione przez „książkołapów”? Wpis proweniencyjny w Satyriconie Petroniusza: „M. Adami Staudij [con]ger Soc. Jes. 1716” każe w to wątpić. Do rozbicia biblioteki doszło najprawdopodobniej po śmierci Mikołaja (ok. $1715 ?^{50}$ ) oraz ostatniego z braci Pinoccich - Jana (zm. 1716). Po jego śmierci spadkobiercy mogli bibliotekę podzielić między siebie, a następnie wyprzedawać bądź przekazywać w darze jej fragmenty. Tak część Pinocciany mógł nabyć lub dostać jako przyjaciel rodziny J.A. Łopacki oraz jezuita A. Staude, który w 1716 r. podpisał się na książkach wchodzących w skład Pinocciany.

Na 1685 pozycji drukowanych, które zapisano w inwentarzu w 1704 r., zidentyfikowano zatem ponad 400 dzieł (ok. 360 w Bibliotece Jagiellońskiej, 59 w Archiwum Narodowym w Krakowie, 20 w Bibliotece Zakładu Narodowego im. Ossolińskich, gdzie jedna pozycja nie została odnotowana w wyżej wymienionym inwentarzu). Nieodkrytych pozostaje ponad 1300 tytułów - można mieć nadzieję, że badania proweniencyjne prowadzone w bibliotekach polskich pozwolą wyłonić kolejne pozycje, równie cenne pod względem bibliograficznym, proweniencyjnym i tegumentologicznym jak te rozpoznane w bibliotece ossolińskiej, przedstawione w poniższym spisie.

Wykaz skrótów cytowanych bibliografii i katalogów

Arbour - R. Arbour, L'Ère baroque en France. Répertoire chronologique des éditions de textes littéraires, Pt. 1-4, Genève 1977-1985.

Adams - Catalogue of books printed on the continent of Europe, 1501-1600 in Cambridge Libraries, comp. by H. M. Adams, vol. 1-2, Cambridge 1967.

Baudrier - H.-L. BAUDRIER, Bibliographie Lyonnaise: recherches sur les imprimeurs, libraires, relieurs et fondeurs de lettres de Lyon au XVI siècle, sèrie 1-12, Paris 1964-1965.

BJ16 - Catalogus librorum saeculi XVI qui in Bibliotheca Iagellonica Cracoviensis asservantur: BJ 16, curavit M. MALICKI, Vol. 1-8, Baden-Baden 2002-2007.

49 Zob. Sprawozdanie z czynności Zakladu narodowego imienia Ossolińskich, czytane na posiedzeniu publicznem dnia 12 października 1866 roku przez Maurycego hr. Dzieduszyckiego kuratora-zastępę, „Biblioteka Ossolińskich” 1868, t. 10, s. 412.

50 Zob. ANK, Archiwum rodziny Pinoccich, rps 386-403, gdzie akta dotyczące Mikołaja Pinocciego kończą się na roku 1715. 
Bohatta - H. BoнAтTA, Katalog der in den Bibliotheken der regierenden Linie des fürstlichen Hauses von und zu Liechtenstein befindlichen Bücher aus dem XVI.-XX. Jahrhundert, Bd. 1-3, Wien 1931.

Brunet - J.-C. BRunet, Manuel du libraire et de l'amateur de livres, T 1-8, Paris 1965-1966.

Estr. XV-XVIII - K. Estreicher, Bibliografia polska, cz. 3: [Stólecie [sic!] XV-XVIII w układzie abecadtowym], t. 1-34, Kraków 1870-1939.

French Books III \& IV - French Books III \& IV. Books published in France before 1601 in Latin and Languages other than French, t. 1-2, wyd. A. PetteGREE, M. WALSBy, Leiden-Boston 2012.

Gültlingen - S. von Gültlingen, Bibliographie des livres imprimés à Lyon au seizième siècle (Bibliotheca Bibliographica Aureliana, 135, 141, 147, 154, 160, 177, 183, 190, 205, 210, 218, 225, 232, 239; Répertoire Bibliographique des Livres Imprimés en France au Seizième Siècle; fasc. hors série), T. 1-14, Baden-Baden-Bouxwiller 1992-2015.

IA - Index Aureliensis. Catalogus librorum sedecimo saeculo impressorum, curavit K. Faust, Ps. 1, Vol. 1-17; Ps. 3, t. 1-3, Aureliae Aquensis: 1965-2014. Ossol. XVI - Katalog starych druków Biblioteki Zakładu Narodowego im. Ossolińskich. Polonica wieku XVI, oprac. M. BoHonos, Wrocław 1965.

Ossol. XVII - Katalog starych druków Biblioteki Zakładu Narodowego im. Ossolińskich. Polonica wieku XVII, t. 1-9, oprac. i indeksy, B. GórsKA, W. Tyszkowski, G. Rolak, Wrocław 1991-1997.

VD 16 - Verzeichnis der im deutschen Sprachbereich erschienenen Drucke des XVI. Jahrhunderts, Abt. 1, t. 1-22, Abt. 2, t. 1-2 (23-24), Abt. 3, t. 1 (25), Stuttgart 1983-2000.

Spis ossolińskich dRUKów z Biblioteki Hieronima Pinocciego

\section{XVI wiek}

1. Cervus, Jan, Syntaxis Ioannis Cervi, Tvcholensis, Accessit Item Aelij Donati doctissimi grammatici de barbarismo libellus. Antonii Mancinelli Veliterni de varia constructione thesaurus, Cracouiae: per Floriannm [sic!] Vnglerium, 1533.

[100] k., sygn. []1, A7, B-L8, M4, N8; $8^{\circ}$.

Estr. XV-XVIII: 14, 131; Ossol. XVI: 333.

Prow.:

1. N¹92 - rps; N. 192 jest to sygnatura biblioteki Hier. Pinocciego (znajduje się w Bibl. Jag.) - rps, prawdopodobnie ręką Kazimierza Piekarskiego;

2. [Józef Maksymilian Ossoliński] 9685/0 - rps;

3. Zakład Nar. Im. Ossolińskich Lwów - superekslibris; 2.199 - pieczęć.

Opr.: skóra brązowa na tekturze, tł. śl. w stylu duseuil, tł. złoc.: IOANNIS CERVI TVCHOLENSIS SYNTAXIS, superekslibris ZNiO, XIX w.

NB.: obfita glossa w jęz. łac. (XVI w.). 
2. Du Bartas, Guillaume de Saluste, La Sepmaine Ov Creation Dv Monde..., [Genève]: Pour la vefue [sic!] de Iean Durant, [post 6 IV] 1588.

[12] k., 623, [1] s.: il. drzewor.; $8^{\circ}$.

Adams: D 961; cf. IA: 156.280.

Prow.:

1. Sustine \& Abstine - rps;

2. Nil Conscire Sibi. Ex Libris H. Lubomirski - ekslibris; XIV Szafa....B. pułka....2. Książka....14. N. K....1317 - rps; Ordyna. Przewor. - pieczęć;

3. Bibliot. Ossolin. - pieczęć; 66.491 - pieczęć.

Opr.: pergamin miękki, XVI w.

NB.: zaw. inf. dot. ceny: Constat $2 \mathrm{fl}$.

XVI.O.8405

3. Gilles, Pierre, Petri Gullii De Bosporo Thracio Libri III, Lvgduni: Apvd Gvlielmvm Rovillivm, 1562.

[3] k., 263 [1]; $4^{\circ}$.

Adams: G 1612; Baudrier: 9, 284; French Books III \& IV: 72069; Gültlingen: 10,560 .

Prow.:

1. Hic Lib. donatus a dno Jacobo Doliński in pignus favoris - rps; Inscriptus Cathalogo Lib. Nico. Chri. Sapiehae - rps;

2. Fris Simonis Okolski S. Th. Mgr. - rps;

3. In Hora Perimvs - rps; Nervus sapientiae non facile credere - rps; Gratia gratiam parit - rps;

4. [Józef Dobek Dzierzkowski - kupno na licytacji w 1840 r. $^{51}$ ] 42/7742 - rps;

5. [Lwów - Ossolineum] 28.261 - pieczęć.

Opr.: półpłótno, karton, papier marmurkowy, XIX w.

XVI.Qu.11643

4. Giraldi Cinzio, Giambattista, Cynthii Ioannis Baptistae Gyraldi Ferrariensis Poematia..., Basileae: (In Officina Roberti Winter, III 1540).

[8] k., 236 s., [2] k.; $8^{\circ}$.

VD 16: G 2115.

Prow.:

6. SIGISMVNDI AVGVSTI REGIS POLONIAE MONVMENTVM ANNO 1559 - tł. na okł. dolnej; [herb Zygmunta II Augusta] - tł. na okł. górnej;

7. Balthasari Czudnikowski Art. et Philo. Doc. Emptus hic liber A. D. 1649.

21 7bris gs 6 -rps;

8. $\mathrm{N}^{\circ} 118-\mathrm{rps}$

9. [Józef Maksymilian Ossoliński] 9806 - rps;

10. Instytut Ossolińskiego - pieczęć; 28.264 - pieczęć.

Opr.: deska, skóra brązowa, tt. śl. i złoc. (superekslibris Zygmunta II Augusta, tł. SIGISMVNDI AVGVSTI..., tyt. IOAN. BAPTIS POEMA, skrócone

${ }^{51} \quad$ BSt. 54/IV/78, k. 2v. nlb., poz. 42. 
inf. bibl. na grzbiecie), resztki metalowych klamer, XVI w.

XVI.O.9591

5. Lambertus Hersfeldensis, Germanorvm Res Praeclare olim gestae..., Tvbingae: Ex Aedibvs Morhardinis, 1 IX 1533.

$15,[1], 256 \mathrm{k}$; $8^{\circ}$.

VD 16: L 162.

Prow: :

1. SIGISMVNDI AVGVSTI REGIS POLONIAE MONVMENTVM ANNO 1559 - tł. na okł. dolnej; [herb Zygmunta II Augusta] - tł. na okł. górnej;

2. $N^{\circ} 196$ - rps na okł. górnej;

3. [Józef Kraiński - kupno na aukcji w 1845 r. ${ }^{52}$ ] 602 - rps;

4. Instytut Ossolińskiego - pieczęć; 40.552 - pieczęć.

Opr:: deska, skóra brązowa, tł. śl. i złoc. (superekslibris Zygmunta II Augusta, tł. SIGISMVNDI AVGVSTI..., tyt. HISTORIAE GERMANORVM), resztki metalowych klamer, XVI w.

XVI.O.9622

6. Petrarca, Francesco, Francisci Petrarchae Florentini, Philosophi, Oratoris, \& Poëtae clarissimi, reflorescentis literaturae Latinaeq[ue] linguae, aliquot seculis horrenda barbarie inquinatae ac pene sepultae, assertoris \& instauratoris, Opera qu[a]e extant omnia..., Basilae: excudebat Henrichus Petri, (III 1554). [14] k., 1375, [1] s., [42] k.; 2.

Adams: P 776; BJ16: P 458; VD 16: P 1708.

Prow.:

1. Op[er]a Francisci Petrarche Georgius Mantl - rps;

2. Io. Michaelis Brutj - rps;

3. $\mathrm{N}^{\circ} 340$ - rps;

4. [Józef Maksymilian Ossoliński] 1330 - rps;

5. Instytut Ossolińskiego - pieczęć; 33.898 - pieczęć.

Opr.: skóra brązowa, XX w., zachowane obleczenie oryg. na okł. górnej: skóra brązowa, tł. śl. i złoc. (plakieta, tł.: OPERA FRANCIS PETRARCH), resztki klamer, XVI w.

XVI.F.13512

7. Silius Italicus, Caius, Silii Italici, Clarissimi Poetae Pvnicoru[m] libri. xvij. alibi in Germania no[n] temere aediti hactenus cum argumentis Hermanni Buschij \& scolijs in margine adiectis..., (Basileae: Apvd Thomam Volfivm, 10 XI 1522).

[4], 234, [2] k.; $8^{\circ}$.

Adams: S 1133; VD 16: S 6479.

Prow. i opr.: zob poz. 4.

XVI.O.9592 adl.

52 BSt. 54/I/28, k. 48r., poz. 132. 
8. Vigenère, Blaise de, Traicte'Des Chiffres, Ov Secretes Manières D'Escrire Par Blaise de Vigenere, Bovrbonnois, Paris: Chez Abel L'Angelier, 1587. 343 [i.e. 331], [1] k., [5] k. tabl. złoż.: il.; $4^{\circ}$.

French Vernacular Books: 50833.

Prow.:

1. Des Noyers - rps;

2. A D [omi]no Des Noyers mihi dono datum A[nn]o 1661. Sustine et Abstine - rps;

3. Ex Libris H. Lubomirski - ekslibris; Ordyna. Przewor. - pieczęć;

4. Bibliot. Ossolin. - pieczęć; 66.120 - pieczęć.

Opr.: pergamin miękki, skórzane wiązania, XVI w.

XVI.Qu.11881

\section{XVII wiek}

9. Bieżanowski, Stanisław Józef, Divi Thomae, De Villa Nova, Eleemosynarij, Archiepiscopi Valentiae, a ... Alexandro ... VII. Anno ... M.DC.LIX. in sanctorum numerum relati, vita sanctissima septem elogiis in Basilica PP. Eremitarum Augustinianoru[m] Casimiriae ad Cracouiam..., Cracoviae: in Officina apud Haeredes Stanislai Lenczewski Bertvt.[owicz], 1663.

[7] k., sygn. )(2, A-C2, D1; $2^{\circ}$.

Estr. XV-XVIII: 3, 107; Ossol XVII: 555.

Prow.:

1. $\mathrm{N}^{\circ} 352-\mathrm{rps}$;

2. [Józef Maksymilian Ossoliński] 9145/1 - rps;

3. Instytut Ossolińskiego - pieczęć; 1.214 - pieczęć.

Opr.: karton, papier marmurkowy, XIX w.

XVII-16223

10. Cikowski, Stanisław, $W$ Sprawach Celnych Odpis ... Z strony Fortelow Kupieckich, Szkodliwych Skarbowi K.J.M. y Koronie, W Krakowie: W Drukarni Lazarzowey, 1602.

84, 74 s.; $4^{\circ}$.

Estr. XV-XVIII: 14, 286; Ossol. XVII: 1196.

Prow.:

4. $\mathrm{N}^{\circ} 588-\mathrm{rps}$

5. [Józef Maksymilian Ossoliński] 7753/14 - rps;

6. Instytut Ossolińskiego - pieczęć; 2.509 - pieczęć; dublet - rps, przekreślony. Opr.: tektura, papier marmurkowy, grzbiet płócienny, XX w.

XVII-446

11. CzARnIECKI, Maksymilian, Virgulae Nvmeratrices Naperianae ... In vsum Studiosorum Matheseos..., Cracoviae: Typis Stanislai Bertvtowic, 1644. [20] k. sygn. A12, B8, [2] k. tabl. złoż.; $12^{\circ}$. 
Estr. XV-XVIII: 14, 523; Ossol. XVII: 1433.

Prow:

1. $\mathrm{N}^{\circ} 212$ - rps;

2. [Józef Maksymilian Ossoliński $9950^{53}$;

3. Instytut Ossolińskiego - pieczęć; 3.020 - pieczęć.

Opr.: karton, papier marmurkowy, XIX w.

XVII-3391

12. (Deductio), Svmmaria. Deductio Juris Illustrissimis Ducibus Curlandiae, In Districtum Piltensem Competentis, Mitaviae: Ex Officina Typographica Illustrissimi Principis Curlandiae, Typis Michaelis Karnall, 1670.

[5] k. sygn. A-B2, A1, [1] k. niesyg., [8] k. sygn. A2, A4, A2, [2] k. niesygn., [1] k. złoż. niesygn.; $2^{\circ}$.

Sumariusz zawiera: historię powiatu piltyńskiego (4 k. sygn. A-B2), Consensus Regius Illustrissimo Curlandiae Duci datus dat 12. VI. 1656 (1 k. sygn. A1); Consensus Regius Domino Maidelio datus dat. 12 VI 1656 (1 k. niesygn.); Der Piltnischen Vollmacht = Piltensium Plenipotentia (2 k. sygn. A2); Die letze Transaction zwischen Ihrer Fürstl. Durchl. Zu Churland und der Piltenschen Landtschafft $=$ Ultimaria Transactio Grobini, inter Illustr[issim]um Curlandiae Ducem \& Nobilitatem Piltensem celebrata dat. 25 II 1661 (4 k. sygn. A4); Rescriptum Regium Contra Petitores Juris Illustrissimi Curlandiae Ducis ad Districtum Piltensem (1 k. sygn. A1); [Dekret] [Inc.:] Serenissimi ac Potentissimi Dni Joannis Casimiri ... Plenipotentiarius. Notum testatumqu[ue] facio ... [sygn.] Casimirus Ludovicus Jewtasiewski dat. 2 IX 1660 (k. A1v-A[2]r.); Joannes Casimirus, Dei Gratia, Rex Polonus ... [Inc.:] Vniversis \& singulis quorum interest ... significamus delatum esse ad Nos ... Ulricum a Sacken obtinuisse Rescriptum ... continens ... mandata quaedam jurisdictionem\& possessionem ... Curlandiae ... Ducis de jure Competentem convellentia dat. 25 VI 1661 (k. sygn. A[2]r.-A[2]v.); Michael Dei Gratia Rex Polonia ... [Inc.:] Significamus praesentibus literis Nostris .... Intercessisse in Judicijs Relationum nostrarum propriarum Anno praesenti ... inter aliquot nobiles Piltenses \& ... Principem ... Jacobum ... dat. 3 VIII 1671 (1 k. niesygn.; jako sekretarz królewski występuje tu Hieronim Pinoc$\mathrm{ci}^{54}$ ); Extractum ex Responsio a Serenissima Republica Poloniae \& Magni Ducat. Lithvaniae in praeterito Electionis actu ... Christophoro Heinrico a Putkamer ... \& Adamo Schubert ... die 6. Julij Anno 1669. Dato (1 k. niesygn.); Joannes Casimirus .... [Inc.:] Universis \& singulis ... significamus ... quemadmodum Nos ad requisitionem \& instantiam Illustrissimi in Livonia Curlandiae \& Semigalliae Ducis, nonnullos Nobiles \& Incolas Districtus Piltensis ... dat. 11 III 1668 (1 k. tabl złoż. niesygn.).

53 BSt., fond 54, księga IV, rps 319, k. nlb z poz. 3020.

54 U Estr. XV-XVIII, 33, 88 tyt. sztucznie nadany: Significatio Michaelis R. Pol. De decreto quondam, in Iudiciis Relationum inter aliquot nobiles Piltenses et principem Iacobum Curlandiae et Semigall. Ducem, intercesso. 
Estr. XV-XVIII: 15, 113 (s.v. Deductio); 14, 370-371 (s.v. Consensus), 24, 282 (s.v. Piltyń); 25, 422 (s.v. Putkamer Henryk Krzysztof); 31, 286 (s.v. Transaction); Ossol. XVII 7151.

Prow.:

1. Sustine. Abstine - rps;

2. Bibliot. Ossolin. - pieczęć; 133633 - pieczęć.

Opr.: karton, papier marmurkowy, I poł. XX w.

XVII-16343

13. Flores, Juan de, Histoire De Avrelio, Et Isabelle, Fille Dv Roy d'Escoce, nouuellement traduict en quatre langues, Italien, Espaignol, François, \& Anglois..., A Brvxelle: Chez Iean Mommart, \& Iean Reyns, 1608. [122] k. sygn.A2, A-O8, P6; $8^{\circ}$.

Brunet: 2, 1303.

Prow.:

1. IN HORA PERIMVS - rps;

2. Henryk X. Lubomirski - pieczęć; Ex Libris H. Lubomirski - ekslibris; XVI. Szafka....B Pułka....4. Książka...17. Katl. Ner....1753 - rps;

3. Ordyna. Przewor. - pieczęć;

4. Bibliot. Ossolin. - pieczęć; 65.847 - pieczęć, rps.

Opr.: pergamin twardy, skórzane wiązania, XVII w.

XVII-10256

14. Haraeus, Franciscus, Francisci Haraei Annales Dvcvm Sev Principvm Brabantiae Totivsq[ve] Belgii. Tomi Tres..., Antverpiae: Ex Officina Plantiniana et Viduam Ioannis Moreti et Io. Meursium, 1623.

T. 1-2: [18] k., 707, [1] s., [58] k.; T. 3: [4] k., 678 s., [59] k.: il. miedzior.; $2^{\circ}$.

Bohatta: 15.889 .

Def.: brak t. 3 .

Prow.:

1. CC - tł. monogram z koroną książęcą na okł. górnej i dolnej [i.e. Karol de Valois?, książę Angoulême, 1573-1650, lub Karol IV, książę Lotaryngii, 1604-1675];

2. Nro $24-$ rps;

3. [Pierre Des Noyers];

4. Munus Ill[ust]r[issi]mi D[omi]ni Petri des Noyers Ser[enissi]mae olim Reginae Poloniae Ludovicae Mariae Consiliarij et Secretarij, mihi datum Varsauiae die 5. Januarij 1668 - rps; Sustine, Abstine - rps; № 6 - rps;

5. Henryk Lubomirski w Krakowie 1830 - rps; VI. Szafa....B. Pułka....12. Ksiązka....7. N. K...5105 - rps;

6. [Lubomirscy - Przeworsk - UJ/Kraków - Ossolineum/Wrocław] 1/51 - rps.

Opr.: skóra czerwona, tł. złoc. w stylu duseuil, XVII w. 


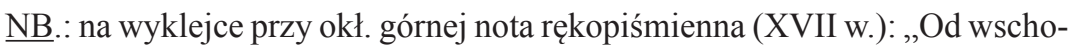
du w szafie po prawey okna z Koper".

XVII-20434

15. Le Mercvre Ou Covrrier Des Affaires Pvbliqves: Pour appre[n]dre a proprement parler, discourir \& escrire, A Paris: De l'Imprimerie d'Anthoine du Brveil, 1613.

[4] k., 182, [1] s., [10] k.; $8^{\circ}$.

Arbour: 20380.

Prow:

1. $\mathrm{N}^{\circ} 8-\mathrm{rps}$

2. IV. Szafa....A. pułka ...3. Ksiązka ...20. N. K....2313 - rps; Ordyna. Przewor. - pieczęć;

3. Bibliot. Ossolin. - pieczęć; 62.247 - pieczęć.

Opr.: tektura, papier, obcięcia prószone, XVIII w.

XVII-10565

16. Petronius Arbiter, Petronii Arbitri Satyricon: Cum vberioribus, Commentarii instar, Notis; concinnias multo \& commodius quam ante dispositis, [Lugduni Batavorum]: Ex Officina Plantiniana Raphelengij, 1604. [12] k., 384 s.; $12^{\circ}$.

Bohatta: 28.158.

Prow.:

1. IN HORA PERIMVS - rps;

2. M. Adami Staudij [con]ger. Soc. Jesu 1716 - rps;

3. Coll: Premisliense Soc. Jesu - rps, częściowo wydrapany;

4. [Dar X. Grzegorza Szymonowicza w 1866 r. ${ }^{55}$;

5. Instytut Ossolińskiego - pieczęć; 55.511 - pieczęć.

Opr.: skóra brązowa, XX w., zachowany fragment obleczenia oryg.: pergamin zapisany tekstem rękopiśmiennym (XV w., tematyka filozoficzna).

XVII-10792

17. PINOCCI, Hieronim, Memoriale Et Articvli Transactionis Ratione deditionis Civitatis Thorunensis, Celsis \& Praepotentibus Dominis D.D. Ordinibvs Generalibvs Foederati Belgii..., [s.1.: s.n.], 1659.

[7] k. sygn. A4, B3; $4^{\circ}$.

Estr. XV-XVIII, 24, 288.

Prow.:

1. $\mathrm{N}^{\circ} 524-\mathrm{rps}$;

2. [Józef Maksymilian Ossoliński] 7766/0 - rps;

3. Instytut Ossolińskiego - pieczęć; 12.477 - pieczęć.

55 Zob. Spis darów uczynionych dla Zaktadu Narodowego imienia Ossolińskich, oraz i dawców tychże w ciagu drugiej połowy roku 1866 i w roku 1867, „Biblioteka Ossolińskich”, 1868, t. 11, s. 399. 
Opr.: karton, papier marmurkowy, XIX w.

NB.: niegdyś współoprawne na pierwszym miejscu w klocku z XVII-4765 (zob. poz. 18).

18. PinOCCI, Hieronim, Memoriael Ende Articulen Van het overgheven van der Stadt Thorn Soo die aende Heeren Staten Generael van de Verernighde Nederlanden..., [s.l.: s.n.], 1659.

13 s., $4^{\circ}$.

Estr. XV-XVIII: 24, 288.

Prow:

1. [ $\left.\mathrm{N}^{\circ} 524\right]$

2. [Józef Maksymilian Ossoliński] 7766/1 - rps;

3. Instytut Ossolińskiego - pieczęć; 12.476 - pieczęć.

Opr.: karton, papier marmurkowy, XIX w.

NB.: niegdyś współoprawne na drugim miejscu w klocku z XVII-4764 (zob. poz. 17).

XVII-4765

19. PInocci, Hieronim, Propositio Nomine Sacrae Regiae Majestatis Poloniae \& Sveciae Celsis Et Praepotentibus Dominis DD. Ordinibvs Generalibvs Foederati Belgii Facta..., [s.1.: s.n.], 1658.

[4] k., sygn. A4; $4^{\circ}$.

Estr. XV-XVIII: 24, 288.

Prow.:

1. $\mathrm{N}^{\circ} 454-\mathrm{rps}$

2. [Józef Maksymilian Ossoliński] 7755/2 - rps;

3. Instytut Ossolińskiego - pieczęć; 12.478 - pieczęć.

Opr.: karton, papier marmurkowy, XIX w.

NB.: niegdyś współoprawne z XVII-6103 (zob. poz. 20).

XVII-4776

20. Pinocci, Hieronim, Propositie weghen den Koningh Van Polen Ende Sveden Gedaen den 21. Augusti aen de Heeren Staten Generael Der Vereenighde Provintien ..., [s.l.: s.n.], 1658.

8 s., $4^{\circ}$.

Estr. XV-XVIII: 24, 288.

Prow.:

4. [N454];

5. [Józef Maksymilian Ossoliński] 7755/1 - rps;

6. Instytut Ossolińskiego - pieczęć; 12.479 - pieczęć.

Opr.: karton, papier marmurkowy, XIX w.

NB.: niegdyś współoprawne z XVII-4776 (zob. poz. 19).

XVII-6103 
Streszczenie

Hieronim Pinocci (1612-1676), włoski kupiec, rajca krakowski i dyplomata, posiadał jeden z cenniejszych wówczas w Polsce księgozbiorów. Książki, prawdopodobnie rozproszone niedługo po jego śmierci, posiadają charakterystyczne znaki biblioteczne (numerus currens i motta), dzięki którym udaje je się zidentyfikować. Celem artykułu jest przedstawienie małej, lecz cennej, kolekcji Pinocciany zidentyfikowanej przez autorkę w Ossolineum.

Słowa kluczowe: Hieronim Pinocci - księgozbiór - Pinocciana - Ossolineum.

\section{Summary}

\section{Pinocciana in the collection of the Ossoliński National Institute's Early Imprints Department}

Hieronim Pinocci (1612-1676), Italian merchant, councilman and diplomat, was also an owner of the one of the most precious book collection in Poland of that time. His books, probably dispersed not long after his death, have characteristic ownerships marks (numerus currens and mottos) which make them easy to identify. The aim of the article is to present small but valuable collection of Pinocci's books recently identified by the author at the Ossolineum library.

Key words: Hieronim Pinocci - book collection - Pinocciana - Ossolineum. 